\title{
ANTIOXIDANT ACTIVITY, TOTAL PHENOL AND TANNIN CONTENT OF DIFFERENT VARIETIES OF FLOURS
}

\author{
Bojana Miladinović ${ }^{1}$, Kristina Ilićn ${ }^{2}$ Dušica Stojanović1 ${ }^{1}$ Milica Kostić1, Milica Milutinović1, \\ Suzana Branković ${ }^{3}$, Dušanka Kitić ${ }^{1}$
}

\begin{abstract}
Cereals are considered one of the most commonly used foods due to their properties. They are the main source of carbohydrates, mainly starch. In addition to carbohydrates, cereals also contain proteins, unsaturated fatty acids, minerals, B-group vitamins and vitamin $\mathrm{E}$. This composition refers to the unprocessed form of cereals - whole grain cereals. They also contain phenolic compounds, such as phenolic acid, flavonoids, stilbene, coumarins and tannins. These are plants secondary metabolites and have a significant role in the prevention of many diseases due to their antioxidant properties.

The aim of this research was to determine the content of total polyphenols and tannins in wheat (type 500), maize, rye and whole wheat flour extracts, as well as the antioxidant activity of the samples. The highest content of total polyphenols was determined in whole wheat flour $(6.38 \pm 0.759 \mathrm{mg} \mathrm{GAE} / \mathrm{g})$, while the lowest amount was determined in wheat (type 500) flour ( $2.29 \pm 0.32 \mathrm{mg} \mathrm{GAE} / \mathrm{g})$. Whole wheat flour extract showed the highest antioxidant activity $\left(\mathrm{IC}_{50}=5.63 \pm 1.331 \mathrm{mg} / \mathrm{ml}\right.$ ), while wheat flour (type 500 ) extract showed the lowest antioxidant activity $\left(\mathrm{IC}_{50}=26.39 \pm 2.132 \mathrm{mg} / \mathrm{ml}\right)$. Based on the results obtained, it can be concluded that whole grain cereals contain a large amount of polyphenols, which indicates a significant antioxidant activity. Due to their many properties, which have effect on improving health, cereals form the base of the pyramid of nutrition, as a model of healthy eating.
\end{abstract}

Acta Medica Medianae 2020;59(2):100-107. activity

Key words: wheat, maize, rye and whole wheat flour, polyphenols, antioxidant

\begin{abstract}
${ }^{1}$ University of Niš, Faculty of Medicine, Department of Pharmacy, Niš, Serbia

${ }^{2}$ University of Niš, Faculty of Medicine, Niš, Serbia

3University of Niš, Faculty of Medicine, Department of

Physiology, Niš, Serbia
\end{abstract}

Contact: Bojana Miladinović

Blagoja Parovića 16/22, 18000 Niš, Serbia

E-mail: bojana.miladinovic@medfak.ni.ac.rs

\section{Introduction}

Cereals are annual plants of grass family (Gramineae) whose seeds or grains are used for human and animal consumption and as an unprocessed material in the food industry. Cereals and cereal products are essential sources of energy, carbohydrates, proteins and fiber, and also contain various micronutrients such as vitamin $E$, thiamine, riboflavin, magnesium and zinc. According to Food and Agriculture Organization of United Nations (FAO), wheat, corn and rice account for $60 \%$ of the world's energy intake.They are inexpensive to produce, easy to store and transport and do not deteriorate quickly if stored in a dry place $(1,2)$.

Cereal grain consists of three basic anatomical parts that differ in function, structure, composition, and all other characteristics. The parts of the grain are: endosperm, germ and bran. The structure of the grain, or its anatomical parts, depends on the cellular structure and chemical composition.

The outer shell of cereal grain - the pericarp, is rich in pentosans, cellulose and minerals. The aleurone layer anatomically belongs to the endosperm and it is removed along with the pericarp in the process of grinding. Aleurone is rich in proteins, lipids, pentosans, minerals and the vitamin B complex. Starch is the main compound of the endosperm. The embryo and scutellum form the germ and contain high contents of protein, lipids, vitamin $E$, sugar (sucrose and raffinose) and minerals (3).

The most important part in the processing of cereals is milling, whereby different types of flours and semolina are obtained. The by-products are bran and flour for animal feed, as well as impurities separated in the preparation process. Flour and semolina come from the endosperm, while animal flour 
and bran originate from the husk and aleurone layer (4).

The milling products of cereals are the basic materials in the baking industry, which produce a various range of baked goods. The most important and used product is bread. The quality of both the dough and the end product depends on the properties of the flour. Composition and properties of flour vary depending on the type of cereals, climatic conditions, applied agro-technical measures, milling methods and storage (4).

\section{Chemical composition of wheat flour}

The chemical composition of the flour depends on the chemical composition of the grain and the type of flour, while the chemical composition of the grain depends on the type and variety of wheat, soil, climate, weather and agro-technical conditions during the growing season (4).

Water is very important factor in the sustainability of flour. With increasing moisture content, the absorption capacity of the flour decreases and thus the bread yield. The water content of the flour is limited by regulations and in our country is at most $15 \%$.

The sugars found in wheat flour are: glucose, fructose, raffinose, maltose, sucrose, melobiose, glucofructose. The amount of sugars, especially maltose, significantly increases in the grain during germination. The total sugar content of wheat flour is about $1 \%$.

Starch makes around $70 \%$ of the flour content. Wheat starch grains are round and size from 5 to $50 \mathrm{~mm}$. The properties of the dough are determined by the starch content in the flour, the size of the starch grains and the degree of their damage. Smaller and damaged starch grains can absorb more water. Starch consists of two macromolecular components: amylose (linear polymer) and amylopectin (branched polymer) (4).

Ballast or dietary fiber is very important from a nutritional aspect, although it is not absorbed in the human body. Dietary fiber present in wheat are cellulose, hemicellulose, lignin, pentosans (3).

Flour lipids are mainly composed of triglycerides of unsaturated fatty acids. Their presence can cause the rancidity of flour. Lipoproteins and glucolipids are also present. The fats are concentrated in the germ, while the rest of the grain contains small amounts. White flour has $1.15-1.8 \%$ fat content and whole grain flour $3.5-4.4 \%$.

Flour proteins are albumins, globulins, gliadins and prolamins. They are directly responsible for the formation of the dough structure by the formation of gluten (4).

Mineral substances of flour are phosphorus, calcium, magnesium, chlorine, potassium. Other minerals are represented in traces. Vitamins are present in flour in very small amounts. Most of them are the $B$ group vitamins (thiamin, riboflavin, niacin, piridoxine), vitamin $E$, vitamin $A(3,5)$.

Whole wheat grain is a rich source of phytochemicals, compounds that participate in or occur in the primary and secondary metabolism of plants. The most important metabolites are phenolic compounds, carotenoids, tocopherols, alkylresorcinols, benzoxazinoids, phytosterols and lignans (6).

Among the phytochemicals found in cereals, phenolic compounds have great attention because of their antioxidant properties. They range from 200 to $1200 \mathrm{mg} / \mathrm{g}$ dry matter (7). Phenolic compounds include phenolic acids, flavonoids, stilbene, coumarins, lignans and tannins. Phenolic acids and flavonoids are most commonly found in cereals (8). The most prevalent phenolic acid in wheat is ferulic acid (> $90 \%$ ). Other derivates of cinnamic acids ( $p$-coumaric, caffeic) and benzoic derivatives ( $p$-hydroxybenzoic, vanillic, gallic, protocatechuic and syringic acid) are also found in wheat flour, but in smaller quantities (9).

Qualitative and quantitative content of phenolic compounds depends on the genotype of wheat, factors of the environment in which it is grown as well as ways of processing and milling of the wheat. The content of phenolic compounds decreases significantly with the increase in the degree of refinement of flour. This is due to the specific distribution of the compounds in the cereal grain. Most phenolic compounds ( $>90 \%$ ) are esterified with cell wall components of the aleurone layer and pericarp, which are discarded during milling (9).

\section{Wheat flour (type 500)}

Type 500 or white flour is the most produced flour used for making bread and bakery products. It is obtained by grinding the central parts of the endosperm. It also has peripheral parts, which gives it a slightly darker color, increased content of minerals, proteins, fats and vitamins compared to flour type 400 (5).

\section{Whole wheat flour}

Whole wheat flour contains all the parts of thewheat grain makes it exceptional in nutritional properties. This type of flour contains starch, proteins, dietary fiber and essential fatty and amino acids, as well as vitamin E. Due to its composition, whole wheat flour is considered to be one of the most complete nutritional foods that are most commonly consumed in the form of bread or other bakery products. The product made of this flour have acceptable sensory characteristics (5).

\section{Corn flour}

Corn flour is flour from whole (integral) grains and therefore commercially prepared food based on corn flour is considered whole grain foods.

Corn (Zea mays L.) originates in the Western Hemisphere and, together with wheat and rice, is the most widely grown grain. Due to its high productivity, it is an economically very important cereal, an important and inexpensive energy source for animal nutrition, as well as a source of starch and sugars used in food industry (3). 
Corn is a tall plant that belongs to the Poaceae family. Grain is located on the cob, and each consists of the seed coat - pericarp, rich in cellulose; aleurone layer - rich in proteins and minerals; endosperm - rich in starch, which is covered with protein matrix and is a source of nutrients; and germs, from which a new plant develops. Corn has the largest grain of all cereals (10).

There are hundreds of different varieties that are distinguished by different composition. They have different endosperm composition as well as protein content. They may also vary in the color of the pericarp, with some being typically yellow, while others may be white, red or blue $(11,12)$.

Some varieties are characterized by high protein content, while others by high lipid content. High lipid content hybrids are used in the diet of domestic animals as they provide high energy intake. However, they are not used in the production of flour, because of the increased risk of lipid oxidation, which reduces the shelf life of these products (11, 12).

The chemical composition of corn, its starch content, as well as the ratio of amylose and amylopectin, the protein and amino acid composition of the protein, to a large extent depend on the hybrid, and in recent times, from the genetic modification. $A$ typical corn kernel consists on average of $70-75 \%$ starch, $8-10 \%$ protein, 4-5\% lipids, 1-3\% sugar (sucrose, glucose, maltose, fructose, galactose, cellobiose, ribose, mannose and xylose) and 1-4\% ash, and is rich in phytosterols. The content of all compounds are genetically controlled and vary between varieties (13).

Proteins are found mostly in the corn endosperm and composition of corn proteins determines the quality of corn. The essential amino acids found in corn are tryptophan, threonine, leucine, isoleucine, lysine, valine, phenylalanine and tyrosine. The proteins found in the germ are different composition than those found in the endosperm, which is of great nutritional importance in grain processing (13).

The highest oil content is in the germ. It is predominant inunsaturated acids (86\%) compared to saturated (14\%) which makes corn oil highly valued. Refined corn oil contains linoleic acid 54$60 \%$, oleic acid $25-31 \%$ and $2 \%$ of linolenic acid. Corn lipids are very stable due to their high content of natural antioxidants (14).

Corn contains provitamin A (carotenoids) and vitamin $E$, especially $\mathrm{Y}$-tocopherolin concentration of $94.1 \mathrm{mg} / 100 \mathrm{~g}$. Vitamins such as thiamine, riboflavin, and nicotinic acid are found most in the aleurone layer $(15,16)$.

The percentage of ash in corn is about 1.3. Minerals found in corn are phosphorus, sodium, potassium, calcium, magnesium and zinc (17).

Corn grains contain polyphenols (tannins, saponins, quercetin), phenolic acids (gallic, chlorogenic, caffeic, hydroxycinnamic, ferulic), flavonoids (anthocyanins, catechins), carotenoids (zeaxanthin, a- and $\beta$-carotene), phytosterols (sitosterol, stigmasterol and campesterol) and other phytochemicals that have shown a beneficial effect on human health $(18,19)$.

\section{Rye flour}

Rye is the youngest cereal compared to other cereals. Cultivated rye (Secalecereale L.) originates from the wild rye of the Mediterranean region Secalemontanum. Rye is genetically close to wheat and barley. After wheat, rye is the most important in the production of bread.

The outer layers of the grain are rich in vitamins, minerals and phytates. Endosperm is rich in starch and proteins, and germs in lipids and proteins. Compared to wheat, rye contains less starch and protein, and more dietary fiber and free sugars. Rye can be successfully used in functional food formulations due to its high fiber, vitamin and mineral content. Rye forms gluten so it cannot be used in the diet of celiac patients (3).

The total lipid content of rye is low, $1.5-2 \%$, and does not differ from wheat and barley grains. Linoleic acid is the most represented fatty acid in rye grains (55.6\%). Rye also contains higher amounts of other lipids than other cereals, followed by palmitic $(16.5 \%)$, oleic $(15.6 \%)$, linoleic $(10.4 \%)$, eicosenoic $(1.3 \%)$ and stearic acid (0.6\%) (10).

Sitosterol in the predominant phytosterol in rye (49-64\%). Other desmethylsterols present in significant amounts are campesterol, stigmasterol, stigmastadienol, as well as saturated sitostanol and campestanol. Total sterol content of rye is higher compared to wheat (10).

Rye grains contain $3.2 \%$ of total soluble sugars, the most common being sucrose $(1.9 \%)$, raffinose $(0.4 \%)$, fructose $(0.1 \%)$ and glucose $(0.08 \%)$ (3).

Rye is the rich source of phytochemicals such as phenolic acids, lignans and alkylresorcinols. There are also found phenolamides, large and diverse group of secondary metabolites which are formed by conjugation of phenolic compounds with polyamides such as spermidine, agmatine and putrescine (20).

Benzoxazinoids contain nitrogen and also are secondary metabolites. The best known benzoxazinodes are 2,4-dihydroxy-1,4-benzoxazin-3-one (DIBOA) and 2,4-dihydroxy-7-methoxy-1,4-benzoxazin-3-one (DIMBOA). All these compounds have been extensively investigated due to their potential positive health effects (20).

\section{The aim}

The aim of this study was to determine the content of total polyphenols (TP) and total tannins (TT) in wheat (type 500), maize, rye and whole wheat flour samples, as well as their antioxidant activity. It was also examined whether there was a statistically significant difference in the content of these compounds in the flour samples as well as in the antioxidant capacity. 


\section{Materials and methods}

\section{Material}

Wheat flour (type 500) was purchased in the supermarket and samples of corn, rye and whole wheat flour were purchased from a local manufacturer.

All flour samples were prepared according to the method of Sedai (21). Briefly, a sample of $10 \mathrm{~g}$ of flour was extracted with $100 \mathrm{ml}$ of $96 \%$ ethanol. The extraction was carried out by stirring for $1 \mathrm{~h}$ at room temperature. The solution was filtered through filter paper (Whatman, UK). The procedure was repeated twice, each with $100 \mathrm{ml}$ of solvent. The filtered solutions $(3 \times 100 \mathrm{ml})$ were combined and evaporated to dryness with a vacuum evaporator. The dry extract was then redissolved in $96 \%$ ethanol to a volume of $10 \mathrm{ml}$. The solutions obtained were used to determine total polyphenols and tannins and antioxidant activity.

\section{Total polyphenols and total tannins}

Total polyphenol content was determined using Folin-Ciocalteu method (22). Total phenolics were expressed as galic acid equivalents (GAE) (mg $\mathrm{GAE} / \mathrm{g}$ juice or extract).

Total tannins were determined using the same Folin-Ciocalteu procedure after removal of tannins by their adsorption on insoluble binding agent (polyvinylpolypyrrolidone, PVPP) (22). The results were expressed as galic acid equivalents (mg $\mathrm{GAE} / \mathrm{g})$.

\section{Antioxidant activity}

This spectrophotometric test measures the antioxidant activity of the flour samples to scavenge 1,1-diphenyl-2-picrylhydrazyl (DPPH) radicals (23). Various concentrations of extracts of $(4 \mathrm{ml})$, were mixed with $1 \mathrm{ml}$ ethanol DPPH solution (0.05 mM) each with vigorous shaking. The control was mixture of solvent and DPPH solution. The absorbance was measured after 30 minutes in the dark at room temperature on UV-VIS spectrophotometer (Evolution 60 Thermo scientific) at $550 \mathrm{~nm}$, as well as controls using the solvent as a blank. The inhibition of DPPH radicals in the presence of the test sample was calculated by the formula and expressed as a percentage (\%):

$$
D P P H \text { radical inhibition }(\%)=(A k-A u) /(A k) * 100 \%
$$

where Ak presents the absorbance of the control reagent and $\mathrm{Au}$ the absorbance of the sample. $\mathrm{IC}_{50}$ value presents the concentration of sample that inhibits $50 \%$ of the initial concentration of DPPH free radicals. $\mathrm{IC}_{50}$ value was calculated from the concentrations/\% inhibition curve. The antioxidant activity was compared to the known antioxidant, ascorbic acid.

\section{Statistical analysis}

Statistical analysis was performed using SPSS software version 20 . The results were processed using one-factor analysis of variance (ANOVA) and the Tukey test determined whether there was a statistically significant difference between samples with a significance level of 0.05 .

\section{Results}

\section{Total polyphenols and tannins}

The content of total polyphenols and tannins are determined by calibration curve, which represents the ratio of increasing concentrations of gallic acid and the obtained absorbance values.

The content of TP and TT in wheat, corn, rye and integral wheat flour extracts are shown in Table 1 in $\mathrm{mg} \mathrm{GAE} / \mathrm{g}$.

Table 1. Content of total polyphenols and tannins ( $\mathrm{mg} \mathrm{GAE} / \mathrm{g}$ ) in wheat, rye, corn and whole wheat flours

\begin{tabular}{||l|c|c||}
\hline \multicolumn{1}{|c|}{ Flour } & $\begin{array}{c}\text { Total polyphenols } \\
\text { (mg GAE/g) }\end{array}$ & $\begin{array}{c}\text { Total tannins } \\
\text { (mg GAE/g) }\end{array}$ \\
\hline \hline Wheat & $2.29 \pm 0.32 \mathrm{a}$ & $0.99 \pm 0.074 \mathrm{a}$ \\
\hline Rye & $2.6 \pm 0.408 \mathrm{a}$ & $1.46 \pm 0.491 \mathrm{a}$ \\
\hline Corn & $5.88 \pm 0.71 \mathrm{~b}$ & $4.27 \pm 0.632 \mathrm{a}$ \\
\hline Whole wheat & $6.38 \pm 0.759 \mathrm{~b}$ & $5.7 \pm 1.547 \mathrm{a}$ \\
\hline
\end{tabular}

a, $b$ Different letters indicate a statistically significant difference $(p<0.05)$ between the samples

The highest content of TP had whole wheat flour extract $(6.38 \pm 0.759 \mathrm{mg} \mathrm{GAE} / \mathrm{g})$ while the lowest had wheat flour extract $(2.29 \pm 0.32 \mathrm{mg}$ $\mathrm{GAE} / \mathrm{g})$. The second by the abundance in TP was corn flour extract $(5.88 \pm 0.71 \mathrm{mg} \mathrm{GAE} / \mathrm{g})$. Statistical analysis revealed that there was no statistically significant difference between the content of total polyphenols of whole wheat flour and corn 
flour. There was a statistically significant difference between wheat flour type 500 and rye flour ( $p<$ 0.05).

The highest content of TT had whole wheat flour extract $(5.7 \pm 1.547 \mathrm{mg} \mathrm{GAE} / \mathrm{g})$ and the lowest wheat flour extract $(0.99 \pm 0.074 \mathrm{mg} \mathrm{GAE} / \mathrm{g})$. There was no statistically significant difference in tannin content between samples ( $p<0.05)$.

\section{Antioxidant activity}

The antioxidant activity of wheat, rye, corn and wheat whole wheat extracts was determined in the DPPH system. The results are shown in Table 2 and are expressed as inhibitory concentrations ( $\mathrm{IC}_{50}$ values). Statistically significant difference (95\%) was found between whole wheat flour and other varieties of tested flour.

Table 2. Antioxidant activity of wheat, rye, corn and whole wheat flours

\begin{tabular}{||l|c||}
\hline \multicolumn{1}{|c|}{ Flour } & IC $_{\mathbf{5 0}} \mathbf{( m g / m I )}$ \\
\hline \hline Wheat & $26.39 \pm 2.132 \mathrm{a}$ \\
\hline Rye & $18.08 \pm 4.112 \mathrm{a}$ \\
\hline Corn & $17.79 \pm 0.491 \mathrm{a}$ \\
\hline Whole wheat & $5.63 \pm 1.331 \mathrm{~b}$ \\
\hline
\end{tabular}

The results show the mean values of the three measurements \pm standard deviation $a, b$ : Different letters indicate statistically significant difference $(p<0.05)$ in antioxidant activity between samples

\section{Discussion}

Phenolic compounds, such as flavonoids, phenolic acids and tannins, express various biological activities, including anti-inflammatory, anticancer and antiatherosclerotic activity. These activities may be related to their antioxidant capacity (24).

Most of the phenols in the cereal grain are located in the cell wall where they are complexed with polysaccharides and lignans. Grinding and processing of cereals reduce their content significantly.

All samples showed a significant amount of total polyphenols and tannins and antioxidant activity.

The study conducted by Mazzoncini et al. (2014) found that the content of phenolic compounds decrease with increased refinement of flour. The content of total polyphenols and tannins was 47 times higher in the bran sample compared to white flour, as well as the antioxidant activity of the same sample (9). The results of this study cannot be fully compared to ours due to the different units ( $\mu \mathrm{mol} \mathrm{GAE} / 100 \mathrm{~g}$ extract), but the wheat flour sample (type 500) also had the lowest total polyphenol content of all whole grain flours (whole wheat, corn and rye flour), which is consistent with our results.

Sedej and associates (2010) also found that the highest amount of total polyphenols was in the whole wheat flour sample and the lowest in the wheat flour type 500 (137.2 $\mu \mathrm{g} \mathrm{GAE} / \mathrm{g}$ and $37.1 \mu \mathrm{g}$ $\mathrm{GAE} / \mathrm{g}$ ) (21). Compared to theirs, our value for the wheat flour (2.29 $\pm 0.32 \mathrm{mg} \mathrm{GAE} / \mathrm{g})$ and whole wheat flour (6.38 $\pm 0.759 \mathrm{mg} \mathrm{GAE} / \mathrm{g})$ are signifi- cantly higher. These differences may be due to the different varieties of wheat, the degree of processing, the agrochemical conditions of production, and the storage of the samples.

Ragaee et al. (2006) determined the content of total polyphenols in wheat, rye, barley, millet and sorghum (25). Several studies have shown that $80 \%$ methanol is the effective solvent for the extraction of phenol and other polar substances from cereals, so the samples were extracted with this solvent. The total polyphenol content of the rye flour sample is $1026 \pm 16.9 \mu \mathrm{g} \mathrm{GAE} / \mathrm{g}$. Our samples were extracted with $96 \%$ ethanol and the content of total polyphenols is twice as high (2.6 $\pm 0.408 \mathrm{mg} \mathrm{GAE} / \mathrm{g})$, indicating the importance of selecting the right solvent for the extraction.

De la Parra et al. (2007) determined the content of total polyphenols in 5 different corn varieties - white, yellow, blue, red and high-carotenoid corn (26). Samples were prepared by extraction with $80 \%$ ethanol. The smallest amount of total polyphenols was found in the red corn sample $(243.8 \pm 4.6 \mathrm{mg}$ $\mathrm{GAE} / 100 \mathrm{~g}$ dry extract) and the highest amount corn with high carotenoid content (320.1 $\pm 7.6 \mathrm{mg}$ GAE/100 g dry corn extract). The white corn sample had twice smaller amount of total polyphenols (260.7 $\pm 6.1 \mathrm{mg}$ GAE/100 g dry extract) compared to our sample (5.88 $\pm 0.71 \mathrm{mg} \mathrm{GAE} / \mathrm{g}$ ) obtained by extraction with $96 \%$ ethanol. As polyphenolic compounds have different solubilities depending on the polarity of the solvent, different amounts of total polyphenols can be expected.

The ability of an extract to remove free radicals depends on its concentration and is expressed as $\mathrm{IC}_{50}$ values. This is the sample concentration required to reduce the initial DPPH radical concen- 
tration by $50 \%$ in experimental conditions. Therefore, a lower $\mathrm{IC}_{50}$ value indicates higher antioxidant activity.

This test demonstrated the antioxidant potential of all flour extracts, and especially the activity of integral wheat flour extract $\left(\mathrm{IC}_{50}=5.63 \pm 1.331\right.$ $\mathrm{mg} / \mathrm{ml}$ ), which was expected due to the highest content of total polyphenols and tannins in this sample.

The lowest antioxidant activity was demonstrated by the wheat flour sample (type 500), whose $\mathrm{IC}_{50}$ value was $26.39 \pm 2.132 \mathrm{mg} / \mathrm{ml}$. Low antioxidant activity was expected, since this sample had the lowest content of total polyphenols.

There are not so many data about flours antioxidative activity. Corn flour, although having approximately the same amount of total polyphenols as whole wheat flour, exhibits slightly lower antioxidant activity $\left(\mathrm{IC}_{50}=17.79 \pm 0.491 \mathrm{mg} / \mathrm{ml}\right)$. Adom et al. (2002) showed that corn had the highest antioxidant activity (181.4 $\pm 0.86 \mu \mathrm{mol}$ equivalent of ascorbic acid/g grain) compared to wheat, rice and oats (27). The results of our study cannot fully be compared to theirs because of the different ways of expression of antioxidant activity.

\section{Conclusion}

Based on the obtained results, the whole wheat flour extract exhibits the best antioxidant activity, while the lowest shows wheat flour type 500. The content of total polyphenols and tannins is highest in the whole wheat flour sample and the lowest in the wheat flour sample.

Cereals are a source of phenolic compounds and the beneficial effects on the body will be manifested if flour and whole grain cereal products are consumed.

\section{Acknowledgments}

This research was supported by the Ministry of Education, Science and Technological Development of the Republic of Serbia (Grant no. III 46013 and III 41018). The authors are also grateful for the financial support of the Internal project of Faculty of Medicine, University of Niš, named "Chemical characterization, biological activity and nutritional value of Ribes nigrum L, Salvia sclarea L. and Foeniculum vulgare Miller".

\section{References}

1. Cardoso RVC, Fernandes A, Gonzaléz-Paramás AM, Barros L, Ferreira ICFR. Flour fortification for nutritionnal and health improvement: A review. Food Res Int 2019;125:108576. [CrossRef] [PubMed]

2. Food and Agriculture Organization of United Nations. [Cited on 2019 October 25] Available from: http://www.fao.org/3/u8480e/U8480E07.htm

3. Pastor K. Autentičnost cerealija i pseudocerealijarazvoj novih metoda analize brašna i gotovih pekarskih proizvoda. Doktorska disertacija. Novi Sad: Tehnološki fakultet; 2018.

4. Auerman $\mathrm{L}$, Beleslin D. Tehnologija pekarske proizvodnje. Tehnološki fakultet, Jugoslovenski institut prehrambenog inžinjerstva za tehnologiju šećera, žita i brašna, skroba i konditorskih proizvoda, 1988.

5. Đaković Lj. Pšenično brašno. Zavod za izdavanje udžbenika, Novi Sad, 1980.

6. Piironen V, Lindsay DG, Miettinen TA, Toivo J, Lampi A. Plant sterols: Biosynthesis, biological function and their importance to human nutrition. J Sci Food Agric 2000;80(7): 839-966. [CrossRef]

7. Andersson AAM, Dimberg L, Aman P, Landberg R. Recent findings on certain bioactive components in whole grain wheat and rye. J Cereal Sci 2014; 59(3): 294-311. [CrossRef]

8. Žilić S. Phenolic compounds of wheat. Their content, antioxidant capacity and bioaccessibility. Food Process Technol 2016;2(3):00037. [CrossRef]

9. Mazzoncini M, Antichi D, Silvestri N, Ciantelli G, Sgherri C. Organically vs conventionally grown winter wheat: Effects on grain yield, technological quality, and on phenolic composition and antioxidant properties of bran and refined flour. Food Chem 2015; 175: 445-51. [CrossRef] [PubMed]

10. Arendt E, Zannini E. Cereal grains for the food and beverage industries. Woodhead Publishing: Elsevier, Cambridge, UK; 2013. [CrossRef] 
11. Johnson LA. Chapter 2: Corn, in: Handbook of Cereal Science and Technology, second edition, CRC Press, Taylor \& Francis; 2000. pp. 32-80.

12. Lookhart G. Chapter 12: Cereal Proteins: Composition of Their Major Fractions and Methods for Identification, in: Handbook of Cereal Science and Technology, second edition, CRC Press, Taylor \& Francis;2000.pp. 363-384.

13. Maize in Human Nutrition - Introduction, Chemical Composition and Nutritional Value of Maize, http://www.fao.org/3/t0395e/T0395E02.htm\#Chapte r 2 - Chemical composition and nutritional value of maize. [CrossRef]

14. CRA. Corn oil ( $5^{\text {th }}$ ed.). Washington, DC: Corn Refiners Association; 2006.

15. Sen CK, Khanna S, Roy S. Tocotrienols: Vitamin E beyond tocopherols. Life Sci 2006;78(18):2088-98. [CrossRef] [PubMed]

16. Shah TR, Prasad K, Kumar P. Studies on physicchemical and functional characteristics of asparagus bean flour and maize flour. In G. C. Mishra (Ed.), Conceptual frame work \& innovations in agroecology and food sciences $1^{\text {st }}$ ed. New Delhi: Krishi Sanskriti Publications;2015.pp.103-105. [CrossRef]

17. Kumar D, Jhariya NA. Nutritional, medicinal and economical importance of corn: A mini review. Res J Pharm Sci 2013;2(7):7-8. [CrossRef]

18. Liu RH. Whole grain phytochemicals and health. J Cereal Sci 2007;46(3):207-19. [CrossRef]

19. Harrabi S, St-Amand A, Sakouhi F, Sebei K, Kallel H, Mayer PM, et al. Phytostanols and phytosterols distributions in corn kernel. Food Chem 2008;111(1):115120. [CrossRef]
20. Pihlava JM, Hellström J, Kurtelius T, Mattila P. Flavonoids, anthocyanins, phenolamides, benzoxazinoids, lignans and alkylresorcinols in rye (Secale cereale) and some rye products. J Cereal Sci 2018; 79:183-92. [CrossRef]

21. Sedej IJ, Sakač MB, Mišan AČ, Mandić AI. Antioxidant activity of wheat and buckwheat flours. Proc Nat Sci 2010;118:59-68. [CrossRef]

22. Hagerman AE, Riedl KM, Jones GA, Sovik KN, Ritchard NT, Hartzfeld PW, et al. High molecular weight plant polyphenolics (tannins) as biological antioxidants. J Agric Food Chem 1998;46(5):1887-92. [CrossRef] [PubMed]

23. Cuendet $M$, Hosttetmann $K$, Potterat O. Iridoid glucosides with free radical scavenging properties from Fagraea blumei. Helvetica Chimica Acta 1997;80(4): 1144-52. [CrossRef]

24. Chung KT, Wong TY, Wei CI, Huang YW, Lin Y. Tannins and human health:a review. Crit Rev Food Sci Nutr 1998;38(6):421-64. [CrossRef] [PubMed]

25. Ragaee S, El-Sayed MAA, Noaman M. Antioxidant activity and nutrient composition of selected cereals for food use. Food Chem 2006;98(1):32-8. [CrossRef]

26. de la Parra C, Saldivar SO, Liu RH. Effect of processing on the phytochemical profiles of antioxidant activity of corn for production of masa, tortillas and tortilla chips. J Agric Food Chem 2007;55(10):4177-83. [CrossRef] [PubMed]

27. Adom KK, Liu RH. Antioxidant activity of grains. J Agric Food Chem 2002;50(21):6182-7. [CrossRef] [PubMed] 


\title{
ANTIOKSIDATIVNA AKTIVNOST, SADRŽAJ UKUPNIH POLIFENOLA I TANINA RAZLIČITIH VRSTA BRAŠNA
}

\author{
Bojana Miladinović ${ }^{1}$, Kristina Ilićc ${ }^{2}$ Dušica Stojanović ${ }^{1}$, Milica Kostić ${ }^{1}$, Milica Milutinović ${ }^{1}$, \\ Suzana Branković ${ }^{3}$, Dušanka Kitić ${ }^{1}$
}

\author{
${ }^{1}$ Univerzitet u Nišu, Medicinski fakultet, Katedra za farmaciju, Niš, Srbija \\ ${ }^{2}$ Univerzitet u Nišu, Medicinski fakultet, Niš, Srbija \\ ${ }^{3}$ Univerzitet u Nišu, Medicinski fakultet, Katedra za fiziologiju, Niš, Srbija
}

Kontakt: Bojana Miladinović

Blagoja Parovića 16/22, 18000 Niš, Srbija

E-mail: bojana.miladinovic@medfak.ni.ac.rs

Žitarice se zbog svojih osobina smatraju jednim od najčešće upotrebljavanih namirnica. One predstavljaju glavni izvor ugljenih hidrata, od kojih u žitaricama najviše ima skroba. Pored ugljenih hidrata, žitarice sadrže i proteine, nezasićene masne kiseline, minerale, vitamine B grupe i vitamin E. Ovaj sastav se odnosi na neprerađen oblik žitarica, tj. na integralne žitarice. Žitarice takođe sadrže fenolna jedinjenja, kao što su fenolne kiseline, flavonoidi, stilbeni, kumarini i tanini. To su sekundarni metaboliti biljaka, koji, zbog svojih antioksidativnih sposobnosti, imaju značajnu ulogu u prevenciji mnogih bolesti.

Cilj ovog rada bilo je određivanje sadržaja ukupnih polifenola i tanina u uzorcima pšeničnog (tip 500), kukuruznog, raženog brašna i integralnog pšeničnog brašna, kao i određivanje njihove antioksidativne aktivnosti. Najveći sadržaj ukupnih polifenola određen je u inte-gralnom pšeničnom brašnu $(6,38 \mathrm{mg} \mathrm{GAE} / \mathrm{g} \pm 0,759 \mathrm{mg} \mathrm{GAE} / \mathrm{g})$, dok je najmanja količina određena u pšeničnom (tip 500) brašnu (2,29 mg GAE/g $\pm 0,32 \mathrm{mg} \mathrm{GAE} / \mathrm{g}$ ).

Najbolju antioksidativnu aktivnost pokazao je ekstrakt integralnog pšeničnog brašna $\left(\mathrm{IC}_{50}=5,63 \mathrm{mg} / \mathrm{ml} \pm 1,331 \mathrm{mg} / \mathrm{ml}\right)$, dok je najslabiju antioksidativnu aktivnost pokazao ekstrakt pšeničnog brašna (tip 500) ( $\mathrm{IC}_{50}=26,39 \mathrm{mg} / \mathrm{ml} \pm 2,132 \mathrm{mg} / \mathrm{ml}$ ). Na osnovu dobijenih rezultata može se zaključiti da brašna od celih zrna žitarica sadrže veliku količinu polifenola, što upućuje na značajnu antioksidativnu aktivnost istih. Zbog svojih mnogobrojnih svojstava, koja utiču na poboljšanje zdravlja, žitarice čine temelj piramide ishrane, kao modela pravilnog načina ishrane.

Acta Medica Medianae 2020;59(2):100-107.

Ključne reči: pšenično brašno, kukuruzno brašno, raženo brašno i integralno brašno, polifenoli, antioksidativna aktivnost 